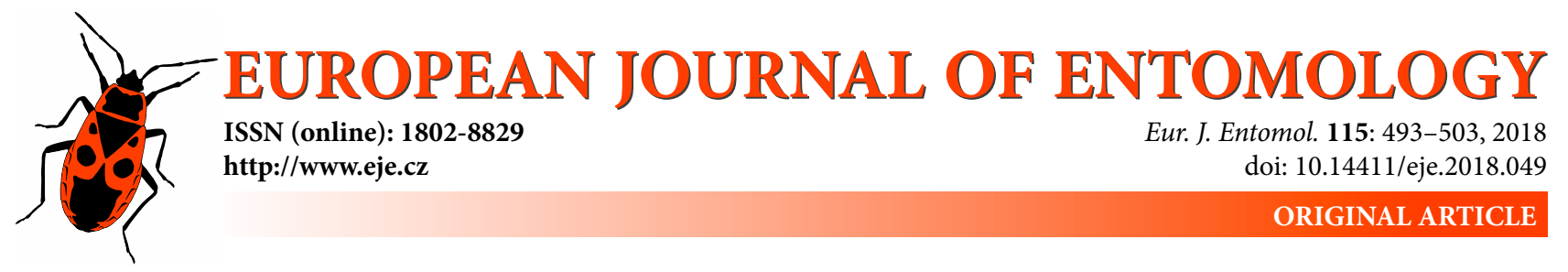

\title{
Demography of the endangered butterfly Euphydryas aurinia (Lepidoptera: Nymphalidae): A case study of populations in sub-Mediterranean dry calcareous grasslands
}

\author{
Jure JUGOVIC ${ }^{1}$, Costanza UBONI ${ }^{2}$, Sara ZUPAN ${ }^{1}$ and Martina LUŽNIK ${ }^{1, *}$ \\ ${ }^{1}$ University of Primorska, Faculty of Mathematics, Natural Sciences and Information Technologies, Glagoljaška 8, 6000 Koper, \\ Slovenia; e-mails: jure.jugovic@gmail.com, sara.zupan@upr.si,martina.luznik@upr.si \\ 2 University of Trieste, Via Giorgieri 10, 34127 Trieste, Italy; e-mail: costanza.uboni@gmail.com
}

Key words. Lepidoptera, Nymphalidae, Euphydryas aurinia, mark-release-recapture, demography, movement, nectar plants, metapopulation, grassland, Slovenia

\begin{abstract}
We studied a population of the regionally endangered marsh fritillary butterfly Euphydryas aurinia inhabiting a system of loosely connected dry calcareous grasslands in sub-Mediterranean Slovenia. Our goal was to set the basis for a long-term monitoring of this butterfly in four meadows using mark-release-recapture (MRR). We determined its demographic parameters, dispersal, behaviour and utilization of nectar plants in different quality patches. Total population size was estimated to be approximately 347 males (95\% confidence interval: 262-432) and 326 females (95\% confidence interval: 250-402), with an unbiased sex ratio. The average lifespans were 6.3 and 8.6 days, respectively. Daily population sizes followed a parabola with marked protandry. Both sexes were relatively highly mobile with both occasionally moving over half a kilometre. The spatial distribution of animals seemed to be associated with patch size, host plant densities and nectar sources, resulting in much higher population densities in the largest patch. Adult behaviour differed between the sexes, with females resting more and flying less than males. Behaviour also changed during daytime and with the progression of the season. Adults were confirmed to be opportunistic feeders, since as many as ten nectar sources were detected. We conclude that demographic parameters differ greatly among regions and habitats, thus conservation aims should be planned accordingly. Although the population studied is apparently in good condition, there are threats that may hamper the long-term persistence of the species in this area: succession, intensification of mowing and overgrazing.
\end{abstract}

\section{INTRODUCTION}

The marsh fritillary, Euphydryas aurinia (Rottemburg 1775) (Lepidoptera: Nymphalidae) is listed in the Habitats Directive 92/43 EEC of the European Union, and included as of least concern in the Red List of Butterflies (van Swaay et al., 2010). In Slovenia, the species is classified as vulnerable in the Red List (Uradni List Republike Slovenije, 2010) and its populations are in general decline, which is around $20 \%$ over the last 20 years, as measured by the number of atlas grid cells it occupies (Verovnik et al., 2012). Declines, or even local extinctions, are reported, especially for populations inhabiting wet meadows in Eastern, but also Central Slovenia; even in protected areas and Natura 2000 sites (Čelik, 2015). This species is well studied throughout its entire distribution, which stretches across Europe to temperate Asia (Gorbunov, 2001; Gorbunov \& Kosterin, 2003; Tolman \& Lewington, 2009) and its demographic parameters differ considerably in different parts of its distribution. It inhabits a wide range of different habitats: e.g. pastures in UK (Asher et al., 2001), hay meadows in central Europe (Anthes et al., 2003; Konvicka et al., 2003), woodland clearings in Scandinavia (Wahlberg et al., 2002a) and Alpine meadows at high altitudes (E. $a$. glaciegenita up to cca. $2300 \mathrm{~m}$ a.s.1.: Casacci et al., 2015). Thus, populations appear to be regionally associated with particular hosts and habitats (Warren, 1994; Anthes et al., 2003) and different evolutionary units are recognised (see Casacci et al., 2014) in Europe. In terms of conservation it should be emphasized that management appropriate for one part of the distribution area would be impractical or even harmful in other areas (Konvicka et al., 2003). Most studies of European populations were done in nutrient poor grasslands and fens in central and northern Europe (Wahlberg et al., 2002a; Konvicka et al., 2003, 2005; Hula et al., 2004; Fric et al., 2010; Zimmermann et al., 2011a, b; Čelik, 2015) and rarely in Mediterranean or Alpine (Singer et al.,

\footnotetext{
* Corresponding author; e-mail: martina.luznik@upr.si
} 
2002; Casacci et al., 2015) habitats. Results of the studies on the Iberian populations of the E. aurinia complex, which have a markedly different ecology (Munguira et al., 1997; Junker \& Schmitt, 2010) were not taken into account as these populations were recently raised from subspecies to the level of a new species, E. beckeri (Korb et al., 2016).

In Slovenia this species' main distribution centres are in the western and south-western part of the country (Verovnik et al., 2012). Populations differ regionally morphologically and ecologically, and in different parts of the country occur as one of the three ecotypes; the first living in marshes and nutrient-poor wet meadows and the second in dry and thermophilous meadows (Čelik, 2015). The latter populations are also present over a wider area of our study site within the sub-Mediterranean climate zone in south western (SW) Slovenia, where this species persists in a system of loosely connected habitat patches. In addition, Alpine meadows are home to the alpine ecotype and morphotype (E. aurinia f. debilis) (Verovnik et al., 2012).

Knowledge of demography is necessary for successful conservation of any species. Since butterflies have complex life cycles, live in metapopulations, which consist of spatially restricted colonies interconnected by dispersal of adults (Warren, 1994; Hanski, 1999; Wahlberg et al., 2002a; Hula et al., 2004), utilize different nectar plants, their dispersal is crucial for the successful conservation and longterm survival of this species in different regions. This species' dispersal ability is important in natural habitats and in increasingly fragmented landscapes that are a by-product of human activities (Zimmermann et al., 2011b). Although some authors (e.g. Warren, 1994) recognise E. aurinia as a sedentary species, it was much later that long distance movements were systematically recorded (Zimmermann et al., 2011b; see also Wahlberg et al., 2002a, b; Schtickzelle et al., 2005; Fric et al., 2010; Casacci et al., 2015). Results of these studies differ greatly, which could be the result of habitat and regional differences within this species.

During a one-season study of a population of E. aurinia inhabiting a system of fragmented patches in dry calcareous meadows in SW Slovenia we aimed to: (i) determine its demographic parameters and movements among patches, (ii) identify its use of habitats and associated different types of behaviour, and (iii) its utilization of nectar plants. Our goal was to set the basis for the long-term monitoring of the allegedly largest Slovenian metapopulation, considering changes in land management during the last 100 years from traditional extensive grazing that preserved open grasslands in the past, towards overgrazing and intensive mowing in some places, or abandonment leading to succession in others.

\section{MATERIALS AND METHODS}

\section{Study species}

Populations of E. aurinia occur in the SW part of Slovenia, from sea level up to around $1250 \mathrm{~m}$ (Verovnik et al., 2012). More particularly, the metapopulation studied inhabits a fragmented semi-natural grassland (Natura 2000 habitat type 62A0) with the following species of plants: Chrysopogon gryllus, Stipa eriocaulis, Danthonia alpina, Carex humilis, Festuca rupicola (all
Festuco-Brometea) and additional submediteranean-illyric species, such as Scorzonera austriaca, Thesium divaricatum, Jurinea mollis, Muscari botryoides, Leontodon crispus, Plantago holosteum, Knautia illyrica (E. aurinia hostplant), Helianthemum ovatum and Serapias vomeracea (Ogorelec, 2007). In this area, dry meadows are secondary open habitats, mostly rocky and highly eroded; many of which have been abandoned and are now completely or partially overgrown with shrub land, consisting of Juniperus communis or Cotinus coggygria, which develops after the abandonment of grazing and traditional mowing (Jogan et al., 2004; Kaligarič et al., 2006; Jugovic et al., 2013).

This species completes its life cycle in such habitats. Females lay eggs in groups (up to 250, rarely more) on the underside of the leaves of its host plant (Wahlberg et al., 2002a; Smee et al., 2011; Nunner et al., 2013). Larvae hatch after three to four weeks (Nunner et al., 2013) and at first live in a common nest. They feed on the host plant and are not very mobile, staying within $50 \mathrm{~cm}$ of their host plant (Liu et al., 2006; Tjørnløv et al., 2015) as they need fresh leaves of nearby host plants. They feed and sunbathe until autumn, when they overwinter in a common waterproof nest. At the beginning of spring larvae stay together for a while and continue to feed, but spread before pupating on leaves or stems of nearby vegetation (Čelik, 2015).

\section{Study site}

The study site is located in SW Slovenia (WGS84: $45^{\circ} 28^{\prime} 51.83^{\prime \prime} \mathrm{N}, 13^{\circ} 56^{\prime} 38.08^{\prime \prime} \mathrm{E}$; Fig. 3) near the village of Rakitovec (Municipality of Koper) at altitudes between 500 and 620 $\mathrm{m}$ a.s.l. on calcareous bedrock of Kraški rob (part of the Slovenian Natura 2000 site named "Kras"). The climate and vegetation here are sub-Mediterranean (Jogan et al., 2004). Four patches (A: 2.22 ha, B: 0.26 ha, C: 0.11 ha, D: 0.25 ha; total area: 2.84 ha) were selected in an area of dry meadows enclosed by primary forests of Quercus pubescens and Ostrya carpinifolia, mixed with secondary pioneer vegetation of Pinus nigra. In some places hedges, consisting mainly of Prunus spinosa and Crataegus spp., separate the habitat patches. The patches consist of fully or at least partially maintained meadows, where mowing slows down succession.

\section{Mark-release-recapture (MRR), population density and life expectancy}

This study was carried out on 14 occasions from $5^{\text {th }}$ May to $5^{\text {th }}$ June 2015 at one to four day intervals, weather permitting (Table 1). On each occasion two people searched for and netted butterflies while walking in a zigzag pattern across the patches. The time spent in each patch was proportional to its size. The duration of each sampling occasion was six hours (from 9 a.m. to 3 p.m.). On the first day we did not find any E. aurinia, therefore we did not include this occasion in the analyses. Each butterfly was individually marked with a black permanent marker and immediately released where it was captured. Prior to netting, the behaviour of each butterfly was recorded (flying, resting, feeding, in copula or courting). When feeding or resting, the species of plant was recorded. We also collected data on the butterfly's individual mark, sex, exact locality and time (date, hour) of a capture (Garmin Oregon 200 , precision $\pm 5 \mathrm{~m}$ ).

We recorded some movement between all four plots; therefore the data on capture were pooled for the study of demographic parameters in MARK 8.0 (White \& Burnham, 1999). Within MARK, we used the POPAN module that indicates the existence of a superpopulation. This approach is suitable for demographic studies of butterfly populations, which change daily due to recruitment from pupae and death of adults, and is often used in such cases (Öckinger \& Smith, 2008; Čelik et al., 2010; Čelik, 
Table 1. Summary of the numbers of males and females of E. aurinia caught in SW Slovenia on 14 occasions in May and June 2015.

\begin{tabular}{|c|c|c|c|c|c|c|c|c|c|c|c|c|c|c|}
\hline Sampling occasion & 1 & 2 & 3 & 4 & 5 & 6 & 7 & 8 & 9 & 10 & 11 & 12 & 13 & 14 \\
\hline Date & 5.05. & 8.05. & 11.05. & 13.05 & 16.05. & 18.05. & 20.05. & 24.05 . & 25.05. & 27.05 . & 29.05. & 1.06. & 3.06 . & 5.06. \\
\hline Interval & 3 & 3 & 2 & 3 & 2 & 2 & 4 & 1 & 2 & 2 & 3 & 2 & 2 & \\
\hline No. of males & 0 & 29 & 44 & 42 & 13 & 53 & 31 & 30 & 23 & 23 & 11 & 10 & 9 & 1 \\
\hline No. of females & 0 & 10 & 21 & 32 & 20 & 31 & 41 & 20 & 27 & 18 & 24 & 23 & 12 & 5 \\
\hline Total no. & 0 & 39 & 65 & 74 & 33 & 84 & 72 & 50 & 60 & 41 & 35 & 33 & 21 & 6 \\
\hline
\end{tabular}

2012; Weyer \& Schmitt, 2013; Pennekamp et al., 2014; Jugovic et al., 2017).

The two-step procedure (Schtickzelle et al., 2003; Čelik, 2012) in MARK was used to select the best models to fit the data. Initially, data were analyzed within the Cormack-Jolly-Seber (CJS) module, which models the probability of survival $(\varphi)$ and capture $(p)$. The best-fitting models were then incorporated into the POPAN module. Within this formulation, we modelled $\varphi, p$ and rate of recruitment (or probability of entrance; $b$ ), which resulted in an estimate of total population size $(N)$ and derived parameters, such as daily population sizes $\left(N_{i}\right)$ and daily recruitment $\left(B_{i}\right)$. The best models were selected using the Akaike Information Criterion corrected for small sample size (AIC $)$ (Burnham \& Anderson, 2002) and choosing models with an $\mathrm{AIC}_{\mathrm{c}}<2$. A goodness-of-fit test for the global model $\left(\varphi_{\left(\mathrm{g}^{*}\right)} p_{\left(\mathrm{g}^{\mathrm{t}_{\mathrm{t}}}\right)}\right)$ was also run in the CJS module, using the median c-hat approach, incorporated in MARK. The resulting estimate of c-hat was then used to correct for overdispersion in the global model of the mark-recapture analysis.

In CJS, we modelled both $\varphi$ and $p$ in eight different ways, allowing them to be constant (.), differ between groups ( $\mathrm{g}$ ), be timedependent $(\mathrm{t})$, show a linear trend (tlin), or arranged in an additive $([\mathrm{g}+\mathrm{t}],[\mathrm{g}+\mathrm{tlin}])$ or interactive way $([\mathrm{g} \times \mathrm{t}],[\mathrm{g} \times \mathrm{tlin}])$, giving a total of 64 different models. In POPAN the additional parameter of recruitment included eight basic and three additional structures $\left(\left[\operatorname{tlin}+\operatorname{tlin}^{2}\right],\left[\mathrm{g}+\mathrm{tlin}+\operatorname{tlin}^{2}\right],\left[\mathrm{g} \times\left[\mathrm{tlin}+\operatorname{tlin}^{2}\right]\right]\right)$. The best models were used to infer the parameters of interest (daily survival, capture probability, daily and total population sizes), using the procedure of model averaging (weighted average of selected best models).

To detect possible effects of weather upon demographic parameters, data on rainfall from the nearest meteorological station located at Rakitovec ( $2.5 \mathrm{~km}$ distant from the study site) was collected from the Slovenian Environmental Agency (National Meteorological Service, 2017).

We used $\chi^{2}$-test of homogeneity $(p<0.05)$ for determining whether the ratios of captures and recaptures differed between males and females.

Population densities (maximum daily number of specimens per hectare) were estimated on the days when males and females were most abundant $\left(N_{i \max } /\right.$ area). In addition, total population densities $(N /$ area) for males and females were also calculated. Densities of captures for males and females were also calculated for each patch in order to determine whether they differed.

We assessed average lifetime expectancy using the method proposed by Nowicki et al. (2005): $\mathrm{e}_{\text {avg }}=(1-\varphi)^{-1}-0.5$. The formula is reported to be suitable for animals that emerge in groups early in the morning (Nowicki et al., 2005).

\section{Behaviour and nectar plants}

We used $\chi^{2}$-test of association to check for possible differences in behaviour and choice of nectar plants by males and females. Since in some cases expected frequencies were lower than 1, likelihood ratio (LR) statistics was used. We compared the frequencies of distribution of five types of behaviour between the sexes, and accepted difference at $p<0.05$. In the same way, we tested for possible differences in behaviour each hour from 9 a.m. to 3 p.m. and on different days, but grouped together for males and females. The frequencies of distribution in the visits to nectar plants were compared between males and females.

In all cases, standardized residuals were used to assess the relative contributions of the cells to the overall $\chi^{2}$ value. Significant contribution was accepted when the absolute value of the standardized residual for the cell was $\geq|2.0|$ (Čelik, 2013). Then we classified plant species used as nectar sources into three categories: rarely $(<3 \%)$, commonly $(3-25 \%)$ and frequently $(>5 \%)$ visited.

To assess differences in plant density in the four patches we counted the numbers and species of nectar and host plants per $\mathrm{m}^{2}$ in 8 to 10 randomly selected squares in each patch and expressed them as average values.

\section{Movements}

To visualize the spatial use within the patches, GPS points of each capture and recapture were graphically presented. For each patch, we counted and calculated the proportions of residential and non-residential males and females. All animals that were marked in one patch but later recaptured in at least one of the other patches were considered as non-residents. We distinguished transferring individuals from transferring events, the latter occurred every time an individual moved between two patches; however, an individual may move between patches more than once. Due to the relatively small number of transfers recorded, we calculated migration, emigration and rate of immigration for the largest plot separately, and for the three smaller patches combined; by merging the data we minimized the statistical error due to the small number of captures recorded in these three patches (Hill et al., 1996). Migration was estimated as the difference between immigration and emigration in a given patch divided by all the recaptures in a given patch. Emigration was the number of butterflies recorded for the first time at one, but later recaptured at another patch, divided by the total number of recaptures of animals from this patch anywhere in the system. Finally, immigration was calculated as the number of butterflies recorded for the first time in any patch, but later recaptured at a given patch, divided by the total number of recaptures of the animals from any other patch recaptured in the given patch. We analyzed both sexes together and expressed the results in terms of percentages of migrating, immigrating and emigrating animals.

We calculated the distances between the successive captures (i.e. $1^{\text {st }}-2^{\text {nd }}$ capture, $2^{\text {nd }}-3^{\text {rd }}$ capture etc.) of all the animals that were recaptured at least once, and compared the ability of males and females in classes of $50 \mathrm{~m}$ distances from the marking point. Average distances and standard deviations were calculated, and possible significant statistical difference between the sexes was tested using a one-way T-test $(\mathrm{p}<0.05)$.

We calculated the cumulative proportions of individuals moving certain multiples of $50 \mathrm{~m}$ and these proportions were then fitted to a negative exponential function, where probability of an individual $(\mathrm{P})$ moving distance $\mathrm{D}$ (in $\mathrm{km}$ ) is $\mathrm{P}=\mathrm{e}^{-\mathrm{kD}}$ ( $\mathrm{k}$ represents a dispersal constant describing the shape of the exponential function). We also calculated the expected distance (D') between two consecutive captures expressed by $D^{\prime}=1 / \mathrm{k}$ (Hill et al., 1996). 
Table 2. Summary of the data on the numbers of males and females of $E$. aurinia caught in SW Slovenia.

\begin{tabular}{lcccccc}
\hline & $\begin{array}{c}\text { No. of marked } \\
\text { individuals }\end{array}$ & $\begin{array}{c}\text { No. of recaptured } \\
\text { individuals }\end{array}$ & $\begin{array}{c}\text { \% of recaptured } \\
\text { individuals }\end{array}$ & No. of captures & No. of recaptures & \% of recaptures \\
\hline Males & 200 & 73 & 36.5 & 318 & 118 \\
Females & 179 & 63 & 35.2 & 285 & 37.1 \\
Total & 379 & 136 & 35.9 & 603 & 33.3 \\
\hline
\end{tabular}

The same data were also fitted by an inverse-power function (IPF), where probability of moving a certain distance is given by $\mathrm{P}=\mathrm{CD}^{-\mathrm{n}}$, with $\mathrm{C}$ and $\mathrm{n}$ representing two scaling constants (Hill et al., 1996). Both approaches are used to estimate the dispersal ability of a species within a landscape and give important information for the species conservation (Pennekamp et al., 2014). We then assessed the slopes and standard errors of the resulting fitted distributions by means of linear regression. The calculations were $\ln \mathrm{P}=-\mathrm{kD}$ in NEF and $\ln \mathrm{P}=\ln \mathrm{C}-\mathrm{n} * \ln \mathrm{n}$ in IPF, respectively. Ttests of the regressions were used to compare the slopes between males and females (Soper, 2016). The population size derived from the MRR analysis was used to calculate the number of individuals capable of moving certain distances.

Statistical analyses were performed using MS Excel 2010 and SPSS statistical package ver. 20.0 (IBM SPSS Inc., 1989, 2011).

\section{RESULTS}

\section{Demographic parameters}

During this study, we marked 379 butterflies (200 males and 179 females; Table 2) of which 136 (73 males and 63 females) were recaptured (35.9\%).

The median c-hat approach indicated a slight overdispersion in the data $(\mathrm{c}-\mathrm{hat}=1.3)$. This was corrected for in both modelling steps: CJS and POPAN. Six of all the models tested had a $\triangle \mathrm{QAIC}_{\mathrm{c}}<2$ and were used for model averaging (Table 3). Survival was predicted to be constant but sex dependent by all six models, whereas probability of capture was only time dependent or time dependent with an additive interaction with sex. Recruitment rate was always linked to some type of linear change in time and differed for the two groups, but with additive or interactive combinations between them.

Average daily survival was $0.853(95 \%$ confidence interval $0.815-0.884)$ for males and 0.890 (95\% confidence interval 0.852-0.919) for females throughout the flying season. Average lifetime expectancy was estimated to be 8.6 days and 6.3 days for females and males, respectively. Maximum lifespan recorded for females surpassed that of males by three days (longest living male recorded: $11^{\text {th }}-29^{\text {th }}$ May) and lasted 21 days (longest living female recorded: $13^{\text {th }}$ May $-3^{\text {rd }}$ June). None of the capture or recapture ratios were biased towards one of the sexes (males: females = $1.12: 1 ; \chi^{2}$-test, $p>0.05$, estimate based on captured animals). Probability of capture was similar for males and females, and decreased over time (Fig. 1a). An unusual and substantial decline in catchability occurred on the $16^{\text {th }}$ May, following two days of rainfall. Peak of male population (13 $3^{\text {th }}$ of May) was a week earlier than that of females $\left(20^{\text {th }}\right.$ of May; Fig. 1c). Daily population sizes of males and females were approximately the same on $18^{\text {th }}$ of May. Emergence of adults into the population or recruitment $\left(B_{i}\right)$ was highest between the first two sampling occasions and declined towards the end of the season (Fig. 1b).

In the area studied, the total population size of males was estimated at 347 (standard error $=43 ; 95 \%$ confidence interval: 262-432), and for females it was 326 (standard error $=39$; 95\% confidence interval: $250-402$ ). The estimated population densities when they were most abundant were 44 males/ha and 39 females/ha. Total population density was 120 males/ha and 112 females/ha. The number of captures was 110 males/ha and 98 females/ha. However, most of the animals were recorded in the largest of the four patches (see patch A, Table 4), where the numbers captured were 132 males and 116 females per hectare. The densities in patch A were at least two times higher than in the smaller patches (Table 4).

\section{Behaviour and nectar plants}

Of the five recorded types of behaviour, flying was recorded in almost two thirds (62\%) of all cases (Fig. 2). In a quarter of cases resting (25\%), followed by feeding (11\%), copula and courtship $(\sim 1 \%$ each) were recorded. Oviposition was not observed. There was a significant difference in behaviour between males and females ( $\mathrm{LR}=17.502$, df $=4, \mathrm{p}=0.002$ ). While the observed frequencies for copula, courtship and feeding did not deviate significantly from the expected frequencies (stand. res. $<|0.6|$ ), males rested less (stand. res. $=-2.2$ ) and flew more (stand. res. $=1.7$, close to significance) than expected. Behaviour of females was

Table 3. The best supported POPAN models according to the Akaike information criterion (with $\left.\triangle \mathrm{AIC}_{\mathrm{c}}<2\right)$, number of parameters $(\mathrm{Np})$ and estimates of population sizes $(N)$ of males $(\hat{O})$ and females $(+)$, with standard errors (SE) and $95 \%$ confidence intervals $(\mathrm{Cl})$.

\begin{tabular}{|c|c|c|c|c|}
\hline Model & $\triangle$ QAIC $_{\mathrm{c}}$ & $\mathrm{Np}$ & $N \lesssim(95 \% \mathrm{Cl})$ & $N+(95 \% \mathrm{Cl})$ \\
\hline$\varphi_{(\mathrm{g})} p_{(\mathrm{t})} b_{\left(\mathrm{g}^{*} \mathrm{tin}\right)} N_{(\mathrm{g})}$ & 0 & 21 & $345(260-429)$ & $312(257-366)$ \\
\hline$\varphi_{(\mathrm{g})} p_{(\mathrm{t})} b_{\left(\mathrm{g}^{*}(\mathrm{tin}+\mathrm{tlin} 2)\right)} N_{(\mathrm{g})}$ & 0.4771 & 22 & $340(281-399)$ & $338(253-422)$ \\
\hline$\varphi_{(\mathrm{g})} p_{(\mathrm{t})} b_{(\mathrm{g}+\text { thin) }} N_{(\mathrm{g})}$ & 0.8186 & 20 & 387 (303-471) & $316(260-372)$ \\
\hline$\varphi_{(\mathrm{g})} p_{(\mathrm{g}+\mathrm{t})} b_{\left(\mathrm{g}^{*} \text { (tin+tlin2)) }\right.} N_{(\mathrm{g})}$ & 1.0158 & 23 & $328(270-385)$ & 354 (259-449) \\
\hline$\varphi_{(g)} p_{(g+t)} b_{\left(g^{*}+\text { tin }\right)} N_{(g)}$ & 1.5372 & 22 & $314(267-360)$ & $314(260-368)$ \\
\hline$\varphi_{(\mathrm{g})} p_{(\mathrm{g}+\mathrm{t})} b_{(\mathrm{g}+\mathrm{tlin})} N_{(\mathrm{g})}$ & 1.8323 & 21 & $366(277-455)$ & 326 (263-389) \\
\hline Model averaging & - & - & 347 (262-432) & $326(250-402)$ \\
\hline
\end{tabular}


a

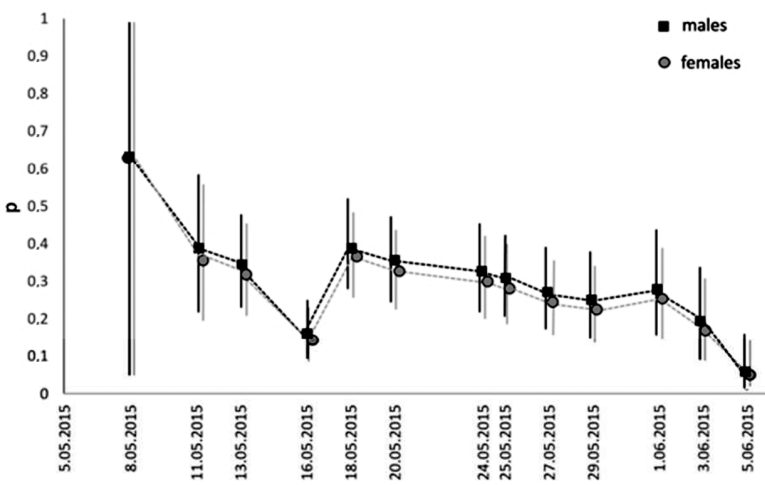

b
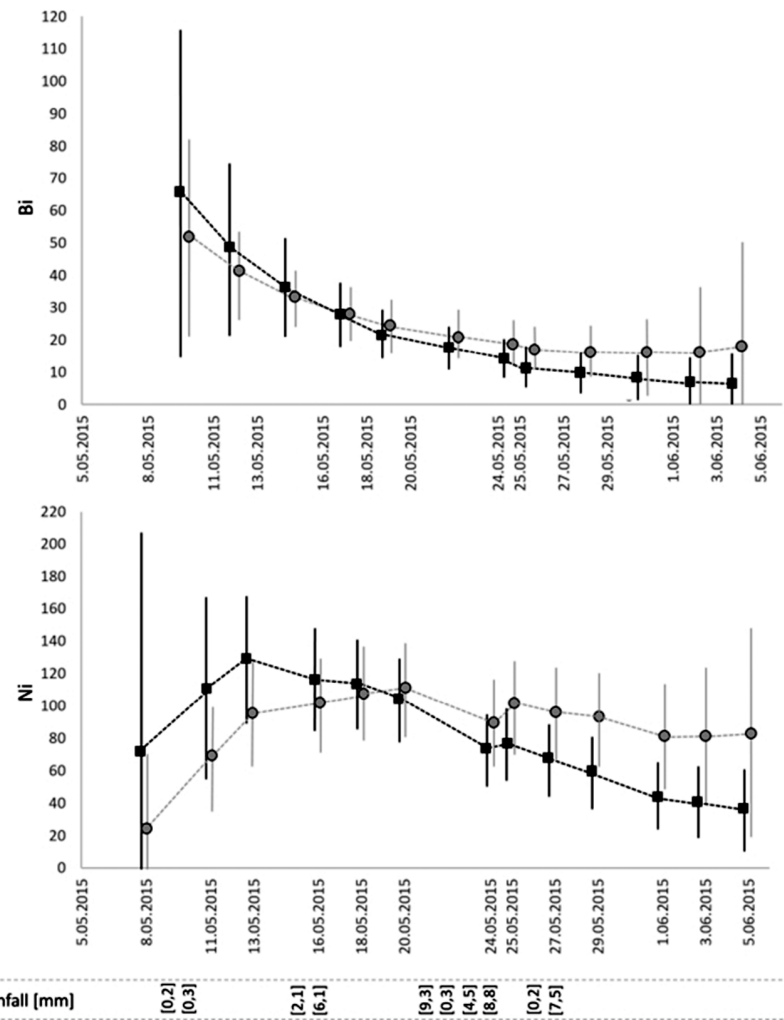

Fig. 1. Estimates and $95 \%$ confidence intervals of (a) probability of capture, (b) daily recruitment and (c) daily population sizes of $E$. aurinia in a karst meadow system in SW Slovenia. Data were obtained by averaging the predictions of the first six models with a $\triangle$ QAIC $<2$. Estimates in (a) and (c) are for the different sampling occasions, and (b) for the intervals between occasions. Data on daily rainfall from the nearest meteorological station at Rakitovec is shown below (c).

the opposite; they flew less (stand. res. $=-1.8$, close to significance) and rested more frequently (stand. res. $=2.3$ ) than expected.

Butterflies changed their behaviour during the course of a day $(\mathrm{LR}=45.619, \mathrm{df}=20, \mathrm{p}<0.001)$. However, there were no deviations from expected frequencies for any of the behaviours in the morning (until 11 a.m.) or afternoon (after 1 p.m.) (stand. res. $<|2.0|$ ), and the significant deviations only occurred around noon (i.e. elevated frequencies of feeding between 11 a.m. and noon (stand. res. = 2.4), and for courtship (stand. res. $=2.0$ ) and copulation (stand. res. $=2.9$ ) between noon and 1 p.m.
Table 4. Summary of the data on nectar and densities of host (Knautia) plants, number of species of nectar plants and densities of captures of males and females in each patch $(A, B, C, D ; T=$ total study area).

\begin{tabular}{|c|c|c|c|c|c|c|}
\hline Patch & & A & B & C & $\mathrm{D}$ & $\mathrm{T}$ \\
\hline No. of quadrats $\left(1 \mathrm{~m}^{2}\right)$ & & 10 & 8 & 8 & 8 & \\
\hline Average no. of nectar plants & & 14.1 & 7.6 & 9.7 & 7.8 & \\
\hline Average no. of Knautia plants & & 5.9 & 1.4 & 2.0 & 3.4 & \\
\hline Average no. of species of nectar plants & & 4.2 & 2.4 & 2.8 & 3.3 & \\
\hline Density of captures & $\hat{\sigma}$ & 132 & 29 & 56 & 48 & 110 \\
\hline & q & 116 & 43 & 56 & 42 & 98 \\
\hline
\end{tabular}

The behaviour of butterflies differed as the season progressed $(\mathrm{LR}=126.935, \mathrm{df}=44, \mathrm{p}<0.001)$. That is, there were significant deviations from the expected frequencies of the following behaviours in the first half of the season: courtship (stand. res. $=3.4$ ) on $13^{\text {th }}$ May, copulation (stand. res. $=2.4$ ) on $13^{\text {th }}$ and $18^{\text {th }}$ May (stand. res. $=2.4$ and 2.1, respectively) and resting on $18^{\text {th }}$ May (stand. res. $=-2.6$ ). In the second half of the season, significant deviations from expected frequencies were recorded for the following behaviours: resting (stand. res. $=2.4$ ), feeding (stand. res. $=$ 2.8 ) and flying (stand. res. $=-2.6$ ) on $25^{\text {th }}$ May, and feeding on $27^{\text {th }}$ May (stand. res. $=5.9$ ) and $3^{\text {rd }}$ June (stand. res. $=$ 2.7).

Patches differed in host and nectar plant densities, with patch A having the highest numbers of plants per $\mathrm{m}^{2}$ (Table 4). In total this butterfly was recorded feeding on ten different plant taxa (Fig. 2). They fed most frequently on Trifolium sp. (27\%) and Leucanthemum sp. (25\%), while other common nectar sources were recorded in the following order: Thymus spp. (11\%), Knautia illyrica, Scorzonera villosa and Lotus corniculatus, each with $8.5 \%$, and Vicia cracca with 5.6\%. Feeding on Polygala nicaensis, Potentilla $\mathrm{sp}$. and Orchidaceae was recorded only occasionally ( $<3 \%$ of all feeding occasions). The choice of nectar plants by the sexes was similar $(\mathrm{LR}=11.546, \mathrm{df}=9 ; \mathrm{p}=0.240)$.

\section{Movements}

Butterflies occupied most of the available space in each of the four patches, which were separated from each other mainly by shrub land and open forest (Fig. 3). Twenty-one individuals (10 males, 11 females, 5.5\%) moved between patches, with two males and two females moving twice and

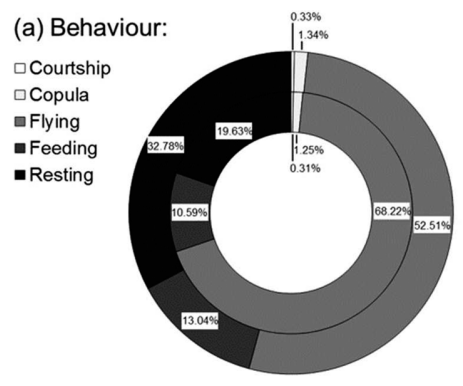

(b) Nectar plants:

Fig. 2. (a) Behaviour of $E$. aurinia in a system of karst meadows in SW Slovenia (males inner circle, females outer circle), and (b) chosen nectar plants (different shades of grey from the lightest to the darkest represent rarely $(<3 \%)$, commonly (3-25\%) and frequently $(>25 \%)$ selected nectar plants, respectively). 


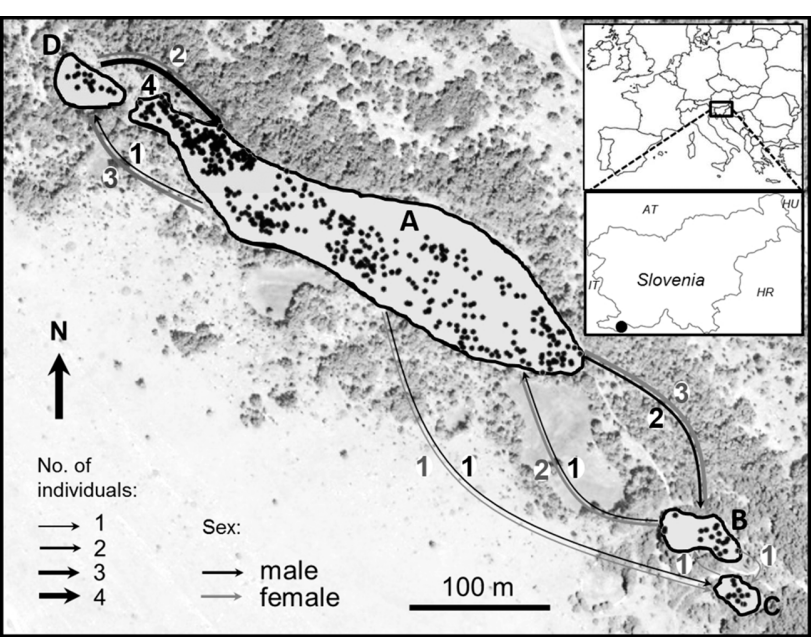

Fig. 3. Geographic position and recorded points of captures and movements of $E$. aurinia between the four patches $(A, B, C, D)$ studied in a system of dry karst meadows in SW Slovenia.

one female moving three times between patches (Fig. 3). Altogether we recorded 27 movements between patches (12 by males and 15 by females). One male moved from patch $A$ to $B$ and back, and another from $A$ to $D$ and back. One female moved from A to B and back, another from A to $\mathrm{D}$ and back and a third moved three times between the patches from A through B to $\mathrm{C}$ and then to B. Other males (8) and females (8) moved between patches only once. All the other butterflies were not recorded outside the patch where they were marked (190 males and 168 females, that is, $95.0 \%$ and $93.9 \%$ of males and females, respectively).

The largest patch seemed to be a source of butterflies for the other patches, since seven males and nine females (76.2\% of the animals that moved) that were recaptured in one of the small patches were first observed and marked in patch A. Only three males (from D to A) and two females (from B and D to A) moved in the opposite direction. Nevertheless, patch $\mathrm{A}$ had the lowest emigration and immigration rates since the total numbers (325: 174 males and 151 females) and proportions (85.8\%: 87.0\% in males and $84.4 \%$ in females) of residential animals there were the highest. In patch C, 12 (7 males, 5 females) out of 15 animals did not move (80.0\%: 87.5 in males and $71.4 \%$ in females), followed by patch B with 11 (5 males and 6 females) out of 15 (61.1\%: 71.4 in males, 54.5 in females) and patch $\mathrm{D}$, with only 10 (5 males, 5 females) out of 22 (45.5\%: 41.7 males and 50.0\% females). Absolute values

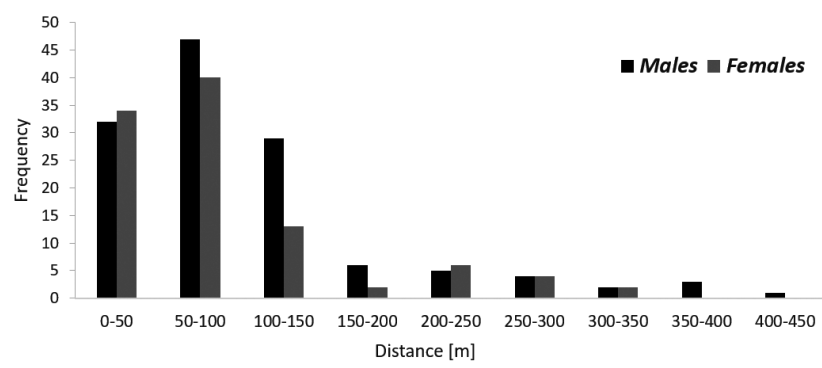

Fig. 4. Distances between two successive captures of recaptured males and females in terms of 50-m distance classes.

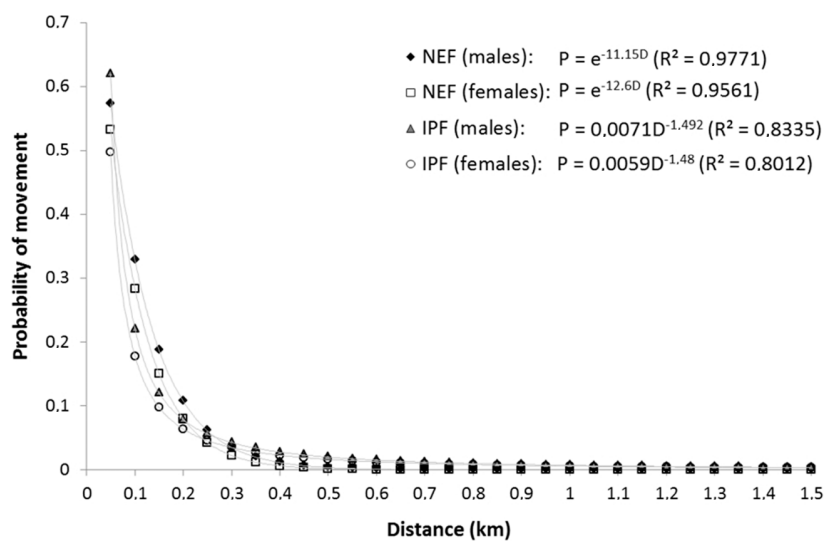

Fig. 5. Probabilities of moving a certain distance for males and females of $E$. aurinia derived from NEF and IPF based on distances between consecutive captures (in the formula, $\mathrm{P}$ represents the probability of moving a certain distance, D).

of rates of migration, emigration and immigration were all smaller for the largest patch (migration/emigration/immigration: $-0.9 \% /-3.0 \% / 2.1 \%$ ) than for all of the three small patches $(10.7 \% / 37.5 \% / 25.0 \%)$.

Altogether, 73 males and 63 females were recaptured from one to five times. Regarding the distances between two successive captures, the proportion of animals recaptured generally decreased with distance (Fig. 4). No statistical difference (T-test, $\mathrm{p}=0.08$ ) was found between the average distance moved by males $(\mathrm{AVG} \pm \mathrm{SD}: 108 \mathrm{~m} \pm$ $80.5 \mathrm{~m})$ and females $(93 \mathrm{~m} \pm 68.3 \mathrm{~m})$. Nevertheless, the greatest distance recorded was for a male, which exceeded that recorded for females (419 $\mathrm{m}$ for males and $348 \mathrm{~m}$ for females).

Both functions predicting probability of long distance movements (NEF and IPF) were a good fit to the data for males and females $(\mathrm{p}<0.001)$. The NEF equations are $\mathrm{P}$ $=\mathrm{e}^{-11.15 \mathrm{D}}$ for males and $\mathrm{P}=\mathrm{e}^{-12.6 \mathrm{D}}$ for females, respectively (Fig. 5). The predicted distance (D') between consecutive captures are $90 \mathrm{~m}$ for males and $79 \mathrm{~m}$ for females. The IPF prediction equals the formulae $\mathrm{P}=0.0071 \mathrm{D}^{-1.492}$ for males and $\mathrm{P}=0.0059 \mathrm{D}^{-1.48}$ for females, respectively. The regression slopes for males and females in both NEF $(\mathrm{t}=0.65, \mathrm{df}$ $=162, \mathrm{p}=0.515)$ and IPF $(\mathrm{t}=0.15, \mathrm{df}=162, \mathrm{p}=0.878) \mathrm{did}$ not differ. The predictions for moving certain distances are summarised in Appendix 1. In general, higher probabilities of movements over distances shorter than $300 \mathrm{~m}$ were estimated by NEF, and higher probabilities for longer distances by IPF. Nevertheless, all equations predict that approximately $10 \%$ or less will move distances greater than $200 \mathrm{~m}$. Moreover, the IPF predicts that less than $2 \%$ of the individuals will reach or move beyond $500 \mathrm{~m}$, and only $1 \%$ will reach $750 \mathrm{~m}$. For males, NEF and IPF predict a higher probability of movements of distances over $100 \mathrm{~m}$ and 500 $\mathrm{m}$ than for females.

\section{DISCUSSION}

\section{Demographic parameters}

The most striking difference between our results and those of many other studies on Euphydryas aurinia is 
that the population size estimate for males and females are nearly the same. Comparable numbers of butterflies of each sex were caught and their probability of capture was similar. In other populations of E. aurinia, many more males than females are reported, and the probability of capturing females is always lower (Wahlberg et al., 2002b; Fric et al., 2010; Zimmermann et al., 2011a,b; Casacci et al., 2015). A sex ratio close to $1: 1$ is uncommon for many butterflies and other insects. The more commonly reported male-sex bias (Ehrlich et al., 1975; Stoks, 2001a, b; Nowicki et al., 2005; Hovestadt \& Nowicki, 2008) is usually interpreted as due to (Ehrlich, 1984) - (i) increased mortality of immature females associated with their prolonged development, (ii) increased mortality of adult females and (iii) higher emigration rate of females. While the first two causes of (un)biased sex ratios remain inconclusive in our case and would need further study, the emigration rate of females (indicated by movements from the largest to the smaller patches) was small (5.02\%) and congruent with an unbiased sex ratio.

Similar to other studies, the probability of capture was time-dependent (Schtickzelle et al., 2002; Vlasanek et al., 2009; Zimmermann et al., 2011a) and most likely affected by weather; e.g. the most marked change in catchability (during the $5^{\text {th }}$ sampling) occurred after heavy rainfall. We can exclude sampling-effort as a cause of differential catchability (cf. Vlasanek et al., 2009), as this remained the same throughout the study.

Difference in the survival rates of males and females of E. aurinia in SW Slovenia is different from that recorded in similar studies, in which survival of males always surpassed that of females (Fric et al., 2010; Zimmermann et al., 2011a); our results indicate the opposite ( 0.853 in males and 0.890 in females). Nevertheless, the estimated constant survival indicates that the rate of loss of butterflies after the emergence from pupae remains constant, with apparently no effect of weather, age at marking or other factors on survival (Fric et al., 2010). We conclude, similar to Zimmerman et al. (2011a), that differently aged animals are equally affected by different causes of mortality.

Higher survival in females is reflected also in their higher average longevity that surpasses the lifespan of males by more than two days. These results contradict other studies (Wahlberg et al., 2002b; Zimmermann et al., 2011a), where the estimated longevity of males is always greater. In our case, males were more active and spent more time flying than females, which could lead to higher energy consumption and a shorter average lifespan in males. Moreover, our estimates of 6.3 and 8.6 days for the average lifespans of males and females, respectively, are lower than reported by Wahlberg et al. (2002a); 10.7 days for males and 8.9 days for females. However, high variability in survival between years and populations within a given year in $E$. aurinia is reported (Zimmermann et al., 2011a,b) and is possibly due to differing temperature conditions, which affect this insects' metabolism and lifespan (Wahlberg et al., 2002b). Wahlberg (2001) suggests that the high lifetime expectancy of E. aurinia is a result of the defensive chemi- cal substances (iridoids) consumed by larvae, which have a positive effect on the survival of adults. Our estimates are comparable or even lower than estimates for some other species of univoltine Melitaeini (e.g. Melitaea athalia, $M$. cinxia, M. diamina, Euphydryas maturna; see Wahlberg et al., 2002b; Konvicka et al., 2005). Casacci et al. (2015) report lower average lifespans for two populations of $E$. $a u$ rinia in North-Western Italy than Wahlberg et al. (2002b); Casacci's results are closer to our estimates, especially for males in the Alpine population they studied (males/females: 6.2 days/5.7 days), and similar for females in the Mediterranean population (males/females: 12.2 days/7.7 days). Their result of a shorter lifespan at higher altitudes indicate the possible negative effect of harsh conditions in the Alps upon the longevity of animals.

As in the other populations of E. aurinia studied (Zimmermann et al., 2011a) and many other univoltine species of butterflies (Fric et al., 2010; Pennekamp et al., 2014), recruitment of adults into the population differed between sexes. Recruitment in our populations was time dependent, being higher for males at the beginning and lower at the end of the season. As a result, parabola shaped daily population sizes are apparent. On two occasions $\left(16^{\text {th }}\right.$ May and $24^{\text {th }}$ May) following long periods ( $\geq 2$ days) of rainfall the $N_{i}$ deviated from expected (see Fig. 1). It is likely that the whole flying season of 2015 was included in our analysis, since no $E$. aurinia were recorded before or after the interval analyzed.

\section{Behaviour, nectar plants and movements}

Feeding is not the most frequent behaviour, although it is important for obtaining energy that can be invested in other activities. This is in line with our observations, since feeding was observed more frequently than expected by chance in late morning and was followed by an increase in the frequency of courtship and copulation. Nevertheless, feeding during the first half of the season, when freshly emerged animals prevailed in the population, was not as frequently recorded as activities associated with reproduction, such as courtship, copulation and mate-locating flight, while resting was less pronounced. It was the opposite in the second half of the season, when butterflies often flew less and rested and fed more.

The detection of as many as ten different nectar sources during our study confirms the assumption that E. aurinia is an opportunistic feeder (Čelik, 2015). It is also reported that an abundance of nectar sources can diminish the emigration rate (Casacci et al., 2015) and is possibly also positively correlated with the density of the animals. The latter was also recorded in our study, in which the number of captures in the largest patch was much higher than in any of the other patches that were also poorer in nectar sources. The estimated density of animals from the MRR study (232 individuals/ha), was substantially higher than reported for most Central European (Czech Republic) and Southern European (Italy) populations (Fric et al., 2010; Casacci et al., 2014; Zimmermann et al., 2011a: 20-379 individuals/ha, always lower than 200 individuals/ha, with one exception). 
The most marked difference in the behaviour of the sexes is that females spend more time resting than males. This is probably due to the mate-locating behaviour of males (van Helsdingen et al., 1996), which involves more flying by males than females. Consequently, the largest distance between two successive captures of males exceeded the largest distance for females. Nevertheless, there was no difference in the average abilities of the sexes to move, as is recorded in other studies (e.g. Casacci et al., 2015). While individuals in some populations do not move very far (Wahlberg et al., 2002a; Anthes et al., 2003; Casacci et al., 2015), the extensive study of Zimmermann et al. (2011a) indicates that E. aurinia is capable of long distance movements. Significant differences among habitats (Casacci et al., 2015), with higher movement reported in Mediterranean compared to Alpine populations, should however be noted. Moreover, in our case long distance movements were predicted for both sexes. This was true even when the better fitting $\left(\mathrm{R}_{\mathrm{NEF}}^{2}>\mathrm{R}_{\text {IPF }}^{2}\right.$, see Results) but underestimating NEF procedure (Baguette, 2003; Zimmermann et al., 2011a) was used. Our study at Kraški rob is in a fragmented landscape, which is well-documented (Jugovic et al., 2013) and in such environments the ability to move long distances is crucial for long-term survival (Euphydryas beckeri: Junker \& Schmitt, 2010). Nevertheless, reports of distances moved can be affected by the scale of the respective study areas [28 ha (Zimmermann et al., 2011b), and our study 2.84 ha], habitat quality and differences (Schneider, 2003; Casacci et al., 2015), which are very hard to estimate. Even applying the conservative estimate of at least $3 \%$ of animals moving a certain distance (Zimmermann et al., 2011a), however, allows us to conclude that currently the metapopulation in the study area (SW Slovenia, see Verovnik et al., 2012 for current data on distribution of $E$. aurinia) is quite large. Verovnik et al. (2012) indicate an area containing loosely connected potential habitats that spans at least $100-140 \mathrm{~km}^{2}$, based on occurrence data.

The dispersal of butterflies between patches is always hazardous, because of the low permeability of vegetation and the increased risk of mortality when moving over long distances. Cassacci et al. (2015) report a high risk of mortality during migration in a metapopulation in a fragmented system of Mediterranean meadows. Unlike the system they studied, where the matrix consisted mainly of woodland, our study site consisted of an open (calcareous meadows) to semi-open (shrub land, open forest) landscape, and the distances between neighbouring patches were much less. Residence rates differed greatly between the largest patch (A) and the other three much smaller patches (B, C, and D). Despite most immigrants and emigrants being captured in patch $\mathrm{A}$, this patch had the lowest migration, emigration and immigration rates. This is in line with the highest total number and density of captured specimens but also with the highest abundance of nectar and host plants in the largest patch, and corroborates the idea of Cassaci et al. (2015), who suggest that the lack of nectar plants can stimulate emigration. In addition, it is also more likely that animals encounter the patch boundary when the patch is small, hence also the higher emigration rate. Since it is impossible to assess the number of butterflies leaving the area, the predicted emigration rate $(4.6 \%$ of animals were recaptured outside the patch where they were marked) is probably an underestimate (see also Hill et al., 1996). This is further supported by the high likelyhood of occasional long distance movements indicated by NEF and IPF. Moreover, Zimmermann et al. (2011a) show that E. aurinia is capable of flying much greater distances (over $15 \mathrm{~km}$ ).

\section{Implications for conservation}

Since E. aurinia lives in metapopulations (Wahlberg et al., 2002a; Anthes et al., 2003; Bulman et al., 2007), it is crucial to estimate the potential it has for moving between patches and how close they need to be. In a sub-Mediterranean part of Slovenia, this species is currently still widespread and patches are apparently close enough for maintaining connections between (sub)populations. Nevertheless, there are some threats to the long-term survival of this species in this area: (i) succession that results in the loss of open habitats rich in nectar sources (Jugovic et al., 2013), (ii) early and multiple mowing of all patches of habitat and baling of hay, and (iii) where still present, overgrazing (van Swaay et al., 2012). While grazing can be beneficial for maintaining open habitats, grazing animals change the structure of vegetation, reduce the abundance and diversity of flowering plants and their faeces are a source of nitrogen. In addition, they can directly harm the population by consuming eggs on host plants (Čelik, 2015). Nonetheless, grazing at Kraški rob is not widespread, but where it does occur the main problem is its intensity (Jugovic et al., 2013). Mowing in late spring can directly harm larvae, pupae and adult butterflies and destroy feeding and nectar plants. Immediate baling of the hay poses a further threat as developing stages of butterflies are directly taken from the area by this activity. Thus, intensification of agriculture can adversely alter the habitats of this species, while moderate traditional practices with a balance of activities can sustain this species' populations.

Given the great diversity of nectar plants used by adults, we argue that meadows with a high plant richness are preferred and an optimal balance between abandonment and intervening actions in these grasslands (occasional mosaic mowing) should be maintained. As the area studied is part of the Natura 2000 network some general guidelines for habitats are established (Bandelj et al., 2014; Čelik, 2015). However, no systematic monitoring and management is currently in place.

The long-term persistence of this species requires relatively large areas (at least $70 \mathrm{ha}$ ) of suitable and continuous habitat (Bulman et al., 2007), yet even larger patches are preferred (100-600 ha; Tjørnløv et al., 2015). The relatively high dispersal ability and density of E. aurinia recorded in this study may indicate a persistent population and a stronghold for this species at the regional scale. Thus, we argue that the minimum viable population criterion for this species (at least 1800 individuals, as proposed by Schtickzelle et al., 2005), would be reached if a wider area of the region had been studied. 
ACKNOWLEDGEMENTS. We would like to thank P. Glasnović (Slovenia) for help with the determination of the nectar plants, $\mathrm{T}$. Čelik (Slovenia) for help with MARK programme and B. Boldin (Slovenia) for help with statistics. CU thanks the European Social Fund that promotes students exchange across Europe. We would like to thank the reviewers for their constructive comments.

\section{REFERENCES}

Anthes N., Fartmann T., Hermann G. \& Kaule G. 2003: Combining larval habitat quality and metapopulation structure The key for succesful management of pre-alpine Euphydryas aurinia colonies. - J. Insect Conserv. 7: 175-185.

Asher J., Warren M., Fox R., Harding P., Jeffcoate G. \& JefFCOATE S. 2001: The Millennium Atlas of Butterflies in Britain and Ireland. Oxford Univ. Press, Oxford, $433 \mathrm{pp}$.

BAGUETTE M. 2003: Long distance dispersal and landscape occupancy in a metapopulation of the cranberry fritillary butterfly. - Ecography 26: 153-160.

Bandelu D., Bužan E.V., Glasnović P., Hladnik M., Jugovic J., LuŽNiK M., Fišer PeČnikar Ž., Zupan S., FazZini M., Furin S. ET AL. 2014: Guidelines for the Conservation of Biodiversity and Cultural Landscape. Padova University Press, Koper, 40 pp. [in Slovenian].

Bulman C.R., Wilson R.J., Holt A.R., Bravo L.G., Early R.I., Warren M.S. \& Thomas C.D. 2007: Minimum viable metapopulation size, extinction debt, and the conservation of a declining species. - Ecol. Appl. 17: 1460-1473.

Burnham K.P. \& ANDERson D. 2002: Model Selection and MultiModel Inference. A Pratical Information-Theoretic Approch. Springer, New York, $488 \mathrm{pp}$.

Casacci L.P., Barbero F. \& Balletto E. 2014: The "Evolutionarily Significant Unit" concept and its applicability in biological conservation. - Ital. J. Zool. 81: 182-193.

Casacci L.P., Cerrato C., Barbero F., Bosso L., Ghidotti S., Paveto M., Pesce M., Plazio E., Panizza G., Balletto E. et al. 2015: Dispersal and connectivity effects at different altitudes in the Euphydryas aurinia complex. - J. Insect Conserv. 19: 265-277.

ČELIK T. 2012: Adult demography, spatial distribution and movements of Zerynthia polyxena (Lepidoptera: Papilionidae) in a dense network of permanent habitats. - Eur. J. Entomol. 109: 217-227.

ČELIK T. 2015: Monitoring of Target Species: The Marsh Fritillary (Euphydryas aurinia). Final Report. Biološki inštitut Jovana Hadžija ZRC SAZU, Ljubljana, 15 pp. [in Slovenian].

ČELIK T. 2013: Oviposition preferences of a threatened butterfly Leptidea morsei (Lepidoptera: Pieridae) at the western border of its range. - J. Insect Conserv. 17: 865-876.

Čelik T., VReš B. \& SelišKar A. 2010: Determinants of withinpatch microdistribution and movements of endangered butterfly Coenonympha oedippus (Fabricius, 1787) (Nymphalidae: Satyrinae). - Hacquetia 8: 115-128.

EHRLICH P.R. 1984: The structure and dynamics of butterfly populations. In Vane-Wright R.I. \& Ackery P.R. (eds): The Biology of Butterflies. Princeton University Press, Princeton, NJ, pp. $25-40$.

Ehrlich P.R., White R.R., Singer M.C., McKechnie S.W. \& GilBERT L.E. 1975: Checkerspot butterflies: a historical perspective. - Science 188: 221-228.

Environmental Agency of the Republic of Slovenia (National Meteorological Service) 2017: Archive. URL: http://meteo. arso.gov.si/ (last accessed 15 Sep. 2017).
Fric Z., Hula V., Klimova M., Zimmermann K. \& Konvicka M. 2010: Dispersal of four fritillary butterflies within identical landscape. - Ecol. Res. 25: 543-552.

Gorbunov P. 2001: The Butterflies of Russia: Classification, Genitalia, Keys for Identification (Lepidoptera, Hesperioidea and Papilionoidea). PhD Thesis, Russian Academy of Sciences, Institute of Plant and Animal Ecology, Ekaterinburg, $320 \mathrm{pp}$.

Gorbunov P. \& Kosterin O. 2003: The Butterflies (Hesperioidea and Papilionoidea) of North Asia (Asian Part of Russia) in Nature. Rodina \& Fodio, Moscow, 408 pp.

HANSKI I. 1999: Habitat connectivity, habitat continuity, and metapopulations in dynamic landscapes. - Oikos 87: 209-219.

van Helsdingen P.J., Willemse L. \& Speight M.C.D. 1996: Background Information on Invertebrates of the Habitats Directive and the Bern Convention: Crustacea, Coleoptera and Lepidoptera. Council of Europe Publishing, Strasbourg, $217 \mathrm{pp}$.

HiLl J.K., Thomas C.D. \& Lewis O.T. 1996: Effects of habitat patch size and isolation on dispersal by Hesperia comma butterflies: Implications for metapopulation structure. - J. Anim. Ecol. 65: 725-735.

Hovestadt T. \& Nowicki P. 2008: Process and measurement errors of population size: Their mutual effects on precision and bias of estimates for demographic parameters. - Biodiv. Conserv. 17: 3417-3429.

Hula V., Konvicka M., Pavlicko A. \& Fric Z. 2004: Marsh Fritillary (Euphydryas aurinia) in the Czech Republic: monitoring, metapopulation structure, and conservation of an endangered butterfly. - Entomol. Fenn. 15: 231-241.

Jogan J., Kaligarič M., Leskovar I., SelišKar A. \& Dobravec J. 2004: Habitat Types in Slovenia: Typology. Ministrstvo za okolje, prostor in energijo, Agencija RS za okolje, Ljubljana, 65 pp. [in Slovenian].

Jugovic J., Črne M. \& FišEr PeČnikar Ž. 2013: The impact of grazing, overgrowth and mowing on spring butterfly (Lepidoptera: Rhopalocera) assemblages on dry karst meadows and pastures. - Nat. Croat. 22: 157-169.

JuGOVIC J., ČRNE M. \& LUŽNIK M. 2017: Movement, demography and behaviour of a highly mobile species: A case study of the black-veined white, Aporia crataegi (Lepidoptera: Pieridae). - Eur. J. Entomol. 114: 113-122.

JunKER M. \& SCHMitT T. 2010: Demography, dispersal and movement pattern of Euphydryas aurinia (Lepidoptera: Nymphalidae) at the Iberian Peninsula: An alarming example in an increasingly fragmented landscape? $-J$. Insect Conserv. 14: 237-246.

Kaligarič M., Culiberg M. \& Kramberger B. 2006: Recent vegetation history of the North Adriatic grasslands: Expansion and decay of an anthropogenic habitat. - Folia Geobot. 41: 241-258.

Konvicka M., Hula V. \& Fric Z. 2003: Habitat of pre-hibernating larvae of the endangered butterfly Euphydryas aurinia (Lepidoptera: Nymphalidae): What can be learned from vegetation composition and architecture? - Eur. J. Entomol. 100: 313322.

Konvicka M., Hula V. \& Fric Z. 2005: Picromerus bidens (Heteroptera: Pentatomidae) as predator of the Checkerspot Euphydryas aurinia (Lepidoptera: Nymphalidae). - Entomol. Fenn. 16: $233-236$.

Korb S.K., Bolshakov L.V., Fric Z. \& Bartonova A. 2016: Cluster biodiversity as a multidimensional structure evolution strategy: Checkerspot butterflies of the group Euphydryas aurinia (Rottemburg, 1775) (Lepidoptera: Nymphalidae). — Syst. Entomol. 41: 441-457.

LiU W., WANG Y. \& XU R. 2006: Habitat utilization by ovipositing females and larvae of the Marsh fritillary (Euphydryas aurinia) 
in a mosaic of meadows and croplands. - J. Insect Conserv. 10: $351-360$.

Munguira M.L., Martín J., García-Barros E. \& Viejo J.L. 1997: Use of space and resources in a Mediterranean population of the butterfly Euphydryas aurinia. — Acta Oecol. 18: 597-612.

Nowicki P., Richter A., Glinka U., Holzschuh A., Toelke U., Henle K., Woyciechowski M. \& Settele J. 2005: Less input same output: Simplified approach for population size assessment in Lepidoptera. - Popul. Ecol. 47: 203-212.

NunNer A., BRÄU M. \& Bolz M. 2013: Goldener Scheckenfalter (Euphydryas aurinia). In Bräu M., Bolz M., Kolcbeck H., Nunner A., Voith J. \& Wolf W. (eds): Tagfalter in Bayern. Eugen Ulmer, Stuttgart, pp. 398-402.

ÖCKInger E. \& Smith H.G. 2008: Do corridors promote dispersal in grassland butterflies and other insects? - Landsc. Ecol. 23: 27-40.

Ogorelec B. 2007: Eastern Sub-Mediteranean Dry Grasslands (Scorzoneretalia villosae). URL: http://www.natura2000.si/ (last accessed 15 Sep. 2017) [in Slovenian].

Pennekamp F., Garcia-Pereira P. \& Schmitt T. 2014: Habitat requirements and dispersal ability of the Spanish Fritillary ( $E u$ phydryas desfontainii) in southern Portugal: Evidence-based conservation suggestions for an endangered taxon. - J. Insect Conserv. 18: 497-508.

SchNeIDER C. 2003: The influence of spatial scale on quantifying insect dispersal: An analysis of butterfly data. - Ecol. Entomol. 28: 252-256.

Schtickzelle N., Le Boulenge E. \& Baguette M. 2002: Metapopulation dynamics of the bog fritillary butterfly: demographic processes in a patchy population. - Oikos 97: 349-360.

Schtickzelle N., Baguette M. \& Le Boulenge E. 2003: Modelling insect demography from capture-re-capture data: comparison between the constrained linear models and the Jolly-Seber analytical method. - Can. Entomol. 135: 313-323.

Schtickzelle N., Choutt J., Goffart P., Fichefet V. \& Baguette M. 2005: Metapopulation dynamics and conservation of the marsh fritillary butterfly: Population viability analysis and management options for a critically endangered species in Western Europe. - Biol. Conserv. 126: 569-581.

Singer M.C., Stefanescu C. \& Pen I. 2002: When random sampling does not work: Standard design falsely indicates maladaptive host preferences in a butterfly. - Ecol. Lett. 5: 1-6.

Smee M., Smyth W., Tunmore M., Ffrench-Constant R. \& HodGSON D. 2011: Butterflies on the brink: Habitat requirements for declining populations of the marsh fritillary (Euphydryas aurinia) in SW England. - J. Insect Conserv. 15: 153-163.

SoPer D. 2016: Free Statistics Calculator, Ver. 4.0. Significance of the Difference between the Two Slopes. URL: http://www. danielsoper.com/statcalc/calculator.aspx?id=103 (last accessed 15 Sep. 2017).

SToKs R. 2001a: Male-biased sex ratios in mature damselfly populations: real or artefact? - Ecol. Entomol. 26: 181-187.

STOKS R. 2001b: What causes male-biased sex ratios in mature damselfly populations? — Ecol. Entomol. 26: 188-197. van Swahy C., Collins S., Dušej G., Maes D., Munguira M.L., Rakosy L., Ryrholm N., Šašić M., Settele J., Thomas J. et al. 2012: Dos and Don'ts for butterflies of the Habitats Directive of the European Union. - Nat. Conserv. 1: 73-153.

van Swaay C., Cuttelod A., Collins S., Maes D., López MunGuira M., ŠAšić M., Settele J., Verovnik R., Verstrael T., Warren M. et AL. 2010: European Red List of Butterfies. Publications Office of the European Union, Luxembourg, 47 pp.

Tuørnløv R.S., Kissling W.D., Barnagaud J.-Y., Bøcher P.K. \& HøYЕ T.T. 2015: Oviposition site selection of an endangered butterfly at local spatial scales. — J. Insect Conserv. 19: 377391.

Tolman T. \& Lewington R. 2009: Collins Butterfly Guide. Harper Collins, London, 384 pp.

Uradni List Republike SloveniJe 2010: Rules on the Inclusion of Endangered Plant and Animal Species in the Red List. Uradni list Republike Slovenije, Ljubljana [in Slovenian].

VEROVNIK R., REBEUŠEK F. \& JEŽ M. 2012: Atlas of Butterflies (Lepidoptera: Rhopalocera) of Slovenia. Center za kartografijo favne in flore, Miklavž na Dravskem polju, $456 \mathrm{pp}$.

VlasaneK P., Hauck D. \& Konvicka M. 2009: Adult sex ratio in the Parnassius mnemosyne butterfly: Effects of survival, migration, and weather. - Isr. J. Ecol. Evol. 55: 233-252.

WAHLBERG N. 2001: The phylogenetics and biochemistry of hostplant specialization in Melitaeine butterflies. - Evolution 55: 522-537.

Wahlberg N., Klemetti T. \& Hanski I. 2002a: Dynamic populations in a dynamic landscape: The metapopulation structure of the marsh fritillary butterfly. — Ecography 25: 224-232.

Wahlberg N., Klemetti T., Selonen V. \& Hanski I. 2002b: Metapopulation structure and movements in five species of checkerspot butterflies. - Oecologia 130: 33-43.

WARREN M.S. 1994: The UK status and suspected metapopulation structure of a threatened European butterfly, the Marsh fritillary Eurodryas aurinia. - Biol. Conserv. 67: 239-249.

Weyer J. \& Schmitt T. 2013: Knowing the way home: Strong philopatry of a highly mobile insect species, Brenthis ino. - J. Insect Conserv. 17: 1197-1208.

White G.C. \& Burnham K.P. 1999: Program MARK: survival estimation from populations of marked animals. — Bird Study 46: S120-S139.

Zimmermann K., Blazkova P., Cizek O., Fric Z., Hula V., Kepka P., Novotny D., Slamova I. \& Konvicka M. 2011a: Demography of adults of the Marsh fritillary butterfly, Euphydryas aurinia (Lepidoptera: Nymphalidae) in the Czech Republic: Patterns across sites and seasons. - Eur. J. Entomol. 108: 243-254.

Zimmermann K., Fric Z., Jiskra P., Kopeckova M., VlasaneK P., ZAPLetal M. \& Konvicka M. 2011b: Mark recapture on large spatial scale reveals long distance dispersal in the marsh fritillary, Euphydryas aurinia. — Ecol. Entomol. 36: 499-510.

Received September 15, 2017; revised and accepted July 24, 2018 Published online September 6, 2018 
Appendix 1. Estimated proportion and number of $E$. aurinia individuals (NEF and IPF models), moving certain distances. Basis for individual measurements were estimates of the population sizes of males $(\mathrm{N}=347)$ and females $(\mathrm{N}=326)$, with their $95 \%$ confidence intervals (males: $\mathrm{N}^{-}-\mathrm{N}^{+}=262-432$; females: $\mathrm{N}^{-}-\mathrm{N}^{+}=250-402$ ).

\begin{tabular}{|c|c|c|c|c|c|c|c|c|c|}
\hline & \multirow{2}{*}{$\begin{array}{c}\text { Distance } \\
(\mathrm{km})\end{array}$} & \multicolumn{4}{|c|}{ Males } & \multicolumn{4}{|c|}{ Females } \\
\hline & & $\%$ individuals & $\mathrm{N}$ individuals & $\mathrm{N}^{-}$ & $\mathrm{N}^{+}$ & $\%$ individuals & $\mathrm{N}$ individuals & $\mathrm{N}^{-}$ & $\mathrm{N}^{+}$ \\
\hline \multirow[t]{13}{*}{ NEF } & 0.05 & 57.26 & 198.71 & 150.03 & 247.38 & 53.26 & 173.62 & 133.15 & 214.10 \\
\hline & 0.1 & 32.79 & 113.79 & 85.91 & 141.66 & 28.37 & 92.47 & 70.91 & 114.03 \\
\hline & 0.15 & 18.78 & 65.16 & 49.20 & 81.12 & 15.11 & 49.25 & 37.77 & 60.73 \\
\hline & 0.2 & 10.75 & 37.31 & 28.17 & 46.45 & 8.05 & 26.23 & 20.11 & 32.34 \\
\hline & 0.3 & 3.53 & 12.24 & 9.24 & 15.23 & 2.28 & 7.44 & 5.71 & 9.17 \\
\hline & 0.4 & 1.16 & 4.01 & 3.03 & 4.99 & 0.65 & 2.11 & 1.62 & 2.60 \\
\hline & 0.5 & 0.38 & 1.32 & 0.99 & 1.64 & 0.18 & 0.60 & 0.46 & 0.74 \\
\hline & 1 & $1.4410^{-3}$ & $4.9910^{-3}$ & $3.7710^{-3}$ & $6.2110^{-3}$ & $3.3710^{-4}$ & $1.1010^{-3}$ & $8.4310^{-4}$ & $1.3610^{-3}$ \\
\hline & 2 & $2.0710^{-8}$ & $7.1710^{-8}$ & $5.4110^{-8}$ & $8.9310^{-8}$ & $1.1410^{-9}$ & $3.7110^{-9}$ & $2.8410^{-9}$ & $4.5710^{-9}$ \\
\hline & 3 & $2.9710^{-13}$ & $1.0310^{-12}$ & $7.7810^{-13}$ & $1.2810^{-12}$ & $3.8310^{-15}$ & $1.2510^{-14}$ & $9.5910^{-15}$ & $1.5410^{-14}$ \\
\hline & 4 & $4.2710^{-18}$ & $1.4810^{-17}$ & $1.1210^{-17}$ & $1.8410^{-17}$ & $1.2910^{-20}$ & $4.2110^{-20}$ & $3.2310^{-20}$ & $5.2010^{-20}$ \\
\hline & 5 & $6.1410^{-23}$ & $2.1310^{-22}$ & $1.6110^{-22}$ & $2.6510^{-22}$ & $4.3610^{-26}$ & $1.4210^{-25}$ & $1.0910^{-25}$ & $1.7510^{-25}$ \\
\hline & 10 & $3.7710^{-47}$ & $1.3110^{-46}$ & $9.8710^{-47}$ & $1.6310^{-46}$ & $1.9010^{-53}$ & $6.210^{-53}$ & $4.7510^{-53}$ & $7.6410^{-53}$ \\
\hline \multirow[t]{13}{*}{ IPF } & 0.05 & 62.00 & 215.14 & 162.44 & 267.84 & 49.70 & 162.03 & 124.26 & 199.80 \\
\hline & 0.1 & 22.04 & 76.49 & 57.75 & 95.22 & 17.82 & 58.09 & 44.54 & 71.63 \\
\hline & 0.15 & 12.04 & 41.77 & 31.54 & 52.00 & 9.78 & 31.88 & 24.44 & 39.31 \\
\hline & 0.2 & 7.84 & 27.19 & 20.53 & 33.85 & 6.39 & 20.82 & 15.97 & 25.68 \\
\hline & 0.3 & 4.28 & 14.85 & 11.21 & 18.49 & 3.51 & 11.43 & 8.76 & 14.09 \\
\hline & 0.4 & 2.79 & 9.67 & 7.30 & 12.04 & 2.29 & 7.46 & 5.72 & 9.21 \\
\hline & 0.5 & 2.00 & 6.93 & 5.23 & 8.63 & 1.65 & 5.37 & 4.11 & 6.62 \\
\hline & 1 & 0.71 & 2.46 & 1.86 & 3.07 & 0.59 & 1.92 & 1.48 & 2.37 \\
\hline & 2 & 0.25 & 0.88 & 0.66 & 1.09 & 0.21 & 0.69 & 0.53 & 0.85 \\
\hline & 3 & 0.14 & 0.48 & 0.36 & 0.60 & 0.12 & 0.38 & 0.29 & 0.47 \\
\hline & 4 & $8.9710^{-2}$ & 0.31 & 0.24 & 0.39 & $7.5810^{-2}$ & 0.25 & 0.19 & 0.30 \\
\hline & 5 & $6.4310^{-2}$ & 0.22 & 0.17 & 0.28 & $5.4510^{-2}$ & 0.18 & 0.14 & 0.22 \\
\hline & 10 & $2.2910^{-2}$ & 0.08 & 0.06 & 0.10 & $1.9510^{-2}$ & 0.06 & 0.05 & 0.08 \\
\hline
\end{tabular}

